\title{
Pengaruh Metode Pembelajaran dan Kemandirian Belajar Terhadap Sikap Siswa Pada Pembelajaran Sejarah di SMA Negeri 3 Karawang
}

\author{
Taupik, Tuti Nuriah, Umasih \\ SMA Negeri 4 Karawang \\ Realipataupik@yahoo.co.id
}

\begin{abstract}
This research is purpose to find out the influence of instructional method and learning autonomy to student's attitude in Karawang Senior High School 3. This research is quantitative type which uses treatment of experiment design method by level $2 x 2$. Both student's attitude and learning autonomy at learning history are used quetionaire instrument. Based on result of research shows that: (1) student' attitude who think pair share learning method is higer than student's attitude who follows conventional learning method (2) there are interactions between learning method and conventional learnig (3) student's attitude of learning history which uses think pair share learning method and high autonomy learning is higer than student's attitude who follows conventional learning method with high aoutonomy learning (4)student's attitude who follows think pair share learning method at learning history is lower than student's attitude who follows conventional learning method with low autonomy learning.
\end{abstract}

Keywords: student's attitude in history learning, learning method, autonomy learning

\begin{abstract}
Abstrak: Penelitian ini bertujuan untuk mengetahui pengaruh metode pembelajaran dan kemandirian belajar terhadap sikap siswa di SMA Negeri 3 Karawang. Jenis penelitian ini termasuk pada penelitian kuantitatif dengan menggunakan metode eksperimen desain treatment by level $2 \times 2$. Instrumen yang digunakan untuk mengukur sikap siswa pada pembelajaran sejarah adalah dengan kuesioner dan untuk mengukur kemandirian belajar digunakan pula kuesioner. Berdasarkan hasil penelitian menunjukkan bahwa: (1) sikap siswa pada pembelajaran sejarah yang mengikuti metode pembelajaran think pair share lebih tinggi dari pada siswa yang mengikuti metode pembelajaran konvensional. (2) terdapat interaksi anatra metode pembelajaran dan kemandirian belajar, (3) sikap siswa pada pembelajaran sejarah yang mengikuti metode pembelajaran think pair share dengan kemandirian belajar tinggi lebih tinggi dari pada siswa yang mengikuti metode pembelajaran konvensional dengan kemandirian belajar tinggi, (4) sikap siswa pada pembelajaran sejarah yang megikuti metode pembelajaran think pair share dengan kemandirian belajar rendah lebih rendah dari siswa yang mengikuti metode pembelajaran konvensional dengan kemandirian belajar rendah.

Kata Kunci : Sikap siswa pada pembelajaran sejarah, metode pembelajaran, kemandirian belajar
\end{abstract}

\section{PENDAHULUAN}

Pembelajaran pada kurikulum 2013 bukan saja mengukur keberhasilan siswa pada nilai akademik saja, namun siswa diukur pula nilai sikap dan keterampilannya, hal ini berimplikasi pada perubahan proses pembelajaran yang dilakukan di kelas. Pelajaran sejarah pada kurikulum 2013 mempunyai posisi yang sangat penting, selain sejarah Indonesia yang wajib dipelajari oleh semua siswa SMA/SMK terdapat pula sejarah 
peminatan yang dikhususkan untuk siswa yang mengambil jurusan ilmuilmu sosial, melalui pembelajaran sejarah siswa diharapkan dapat mempunyai sikap dan karakter bangsa sesuai harapan pemerintah yang gencar disosialisasikan pada kurikulum 2013.

Berdasarkan observasi awal yang di lakukan di SMA Negeri 3 Karawang pada pembelajaran sejarah di kelas XI IIS 1 ditemukan beberapa permasalahan yang muncul diantaranya adalah: kurang aktifnya siswa dalam mengikuti pembelajaran, metode yang digunakan tidak membuat siswa antusias, tingkat kreatifitas dan kemandirian belajar siswa masih rendah, dan minat belajar sejarah siswa pada pembelajaran sejarah sangat kurang

Sebagai upaya meningkatkan sikap siswa pada pembelajaran sejarah di SMA Negeri 3 Karawang maka dibutuhkan metode pembelajaran yang dapat membuat siswa aktif dan turut berpartisipasi di dalamnya. Judul pada penelitian ini adalah pengaruh metode pembelajaran dan kemandirian belajar terhadap sikap siswa pada pembelajaran sejarah di SMA Negeri 3 Karawang.

Sikap adalah suatu perilaku yang ditunjukan oleh individu, prilaku tersebut dapat berupa hal positif maupun negatif tergantung pad penilaian. Sikap itu dinyatakan dalam tingkah laku yang sesuai dan konsisten dengan sikap batin, kemampuan itu dinyatakan dalam suatu perkataan atau tindakan.(Wingkel: 2014)

Perilaku yang ditunjukan siswa di kelas pada proses pembelajaran merupakan suatu hal yang penting, perilaku tersebut merupakan respon atas apa yang ia lihat dan rasakan. Sikap yang ditunjukan di nilai oleh orang lain dengan dua penilaian secara umum yaitu positif dan negatif

Pada umumnya sikap mempunyai kebersamaan unsur, yaitu suatu respon terhadap situasi, sikap mengandung tiga komponen, yaitu: kognitif, afektif, dan tingkah laku, pada suatu pernyataan sikap dapat ditunjukan dengan dua hal yaitu positif dan negatif (Gagne: 2000)

Jenis pembelajaran kooperatif dirasa perlu dan mampu meningkatkan aktifitas dan respon siswa pada pembelajaran sejarah, pembelajaran dengan cara kerja sama ini dilakukan dengan teman kelompok, baik dengan kelompok bersekala kecil maupun besar, Slavin menjelaskan bahwa tujuan pembelajaran kooperatif adalah meningkatkan pengetahuan, konsep, kemampuan dan pemahaman siswa

Pembelajaran dengan kooperatif salah satunya dengan cara diskusi kelompok, pembelajaran dengan pengelompokan secara berpasangan merupakan suatu cara pengajaran sosial yang paling sederhana, aktivitas dalam pembelajaran kooperatif dilaksanakan dalam bentuk kelompok dua atau tiga siswa agar lebih sederhana.(Joyce: 2009) 
Pada pelaksanaanya pembelajaran kooperatif lebih efektif, efisien dan sederhana, sehingga diharapkan siswa lebih antusias mengikuti proses pembelajaranya. Think Pair Share (TPS) atau lebih dikenal dengan berpikir berpasang-pasangan merupakan salah satu metode pembelajaran jenis kooperatif, pembelajaran dengan metode ini mempunyai tujuan untuk meningkatkan partisipasi siswa pada proses pembelajaran di kelas.

TPS dapat efektif karena tiga alasan, pertama strategi ini mengundang respon dari semua orang di dalam kelas dan menempatkan siswa kedalam peran-peran yang aktif secara kognitif, kedua karena setiap anggota dari pasangan aktif berpartisipasi maka dapat mengurangi kecendrungan "penumpang gratisan" yang biasa menjadi masalah saat pengerjaan kelompok dan yang ketiga adalah strategi ini mudah direncanakan dan diterapkan. (Eggen dan Kauchak: 2012)

Pada awalnya kegiatan diskusi dilakukan pada kelompok kecil yang terdiri dari dua atau tiga orang, kemudian hasil diskusinya disampaikan kembali pada rekan yang lainya di depan kelas hal ini membuat seluruh siswa turut partisipasi.

Kemandirian belajar merupakan suatu tindakan siswa yang dilakukan dalam upaya melaksanakan pembelajaran tanpa meminta bantuan dari orang lain, siswa yang mandiri pada pembelajaran mempunyai inisiatif dalam perencanaan, pelaksanaan dan evaluasi, sehingga ia tidak banyak meminta bantuan orang lain. Siswa dikatakan mempunyai kemandirian dalam belajar karena telah melakukan langkah-langkah tertentu, pada umumnya proses yang harus diikuti siswa yang mandiri mengikuti siklus rencanakan, kerjakan, pelajari, lakukan dan tindakan. (Johnson: 2006)

Langkah pertama siswa yang mandiri adalah dengan merencanakan proses pembelajaran, apa saja yang ia perlukan dan apa saja yang akan ia lakukan pada kegiatan pembelajaran telah disiapkan sebelumnya, langkah selanjutnya adalah pelaksanaan pembelajaran di kelas yang sebelumnya ia rencanakan, setelah itu akan mempelajari tindakan yang ia lakukan untu dilakukan evaluasi terhadap tindakanya kemudian terakhir merealisasikan hasil evaluasinya.

Siswa yang melakukan kemandirian dalam belajar akan berusaha mengendalikan perilakunya ke arah yang baik, agar ia tidak merugikan atau menyusahkan orang lain. Kemandirian sebagai kemampuan untuk mengarahkan dan mengendalikan diri dalam berpikir dan bertindak, serta tidak merasa bergantung pada.(Uno: 2008)

Penelitian ini membahas mengenai pengaruh metode pembelajaran dan kemandirian belajar terhadap sikap siswa pada pembelajaran sejarah di SMA Negeri 3 Karawang. Metode yang digunakan pada kelas eksperimen adalah metode TPS dan pada kelas kontrol metode konvensional. 


\section{METODE}

Pada penelitian ini Metode yang digunakan adalah metode kuantitatif dengan pendekatan eksperimen, metode ini digunakan untuk menguji pengaruh penerapan metode pembelajaran think pair share yang ditetapkan sebagai variabel bebas $X_{1}$, dan kemandirian belajar yang ditetapkan sebagai variabel bebas $X_{2}$ terhadap sikap siswa pada pembelajaran sejarah sebagai variabel terikat $Y$. Penelitian ini menggunakan desain treatment by level $2 \times 2$.

Populasi pada penelitian ini adalah seluruh siswa SMA Negeri 3 Karawang kelas XI. Penarikan sampel untuk kelompok eksperimen dan kelompok kontrol diambil secara acak, objek penelitian kelas XI IIS 1 merupakan kelas eksperimen dan XI IIS 3 sebagai kelas control, dengan total jumlah 64 orang masing-masing kelas terdiri dari 32 orang, sebelum adanya perlakuan dilakukan pengumpulan data kemandirian belajar yang diperoleh melalui guru kelas.

Sebelum penelitian setiap kelas diambil 27\% ranking teratas siswa dengan kemandirian belajar tinggi sebanyak 9 orang, serta 27\% ranking terbawah siswa dengan kemampuan belajar rendah sebanyak 9 orang, total keseluruhan sebanyak 18 siswa dengan kemandirian belajar tinggi dan siswa dengan kemampuan belajar rendah, untuk memenuhi sarat uji hipotesis, dilakukanlah uji prasyarat yang terdiri dari uji normalitas dan uji homogenitas variansi. Uji normalitas dengan menggunakan uji Liliefors, Uji homogenitas pada penelitian ini dengan menggunakan uji Barlett sebagai cara untuk mengetahui variansi kelompok homogen atau tidak. Pengujian hipotesis pada penelitian ini dengan analisis varians dua jalur (ANAVA 2X2).

HASIL

Rangkuman hasil perhitungan analisis varians dua jalur dengan statistik secara lebih lengkap disajikan pada tabel berikut 
Tabel 1.

Rangkuman Hasil Perhitungan Analisis Varians (ANAVA) Dua Jalur

\begin{tabular}{|c|c|c|c|c|c|c|}
\hline \multirow{2}{*}{ Sumber Variansi } & \multirow{2}{*}{$\mathrm{Db}$} & \multirow{2}{*}{ JK } & \multirow{2}{*}{ RJK } & \multirow{2}{*}{ F hitung } & \multicolumn{2}{|c|}{$F_{\text {tabel }}$} \\
\hline & & & & & 0,05 & 0,01 \\
\hline Metode Pembelajaran (A) & 1 & 210,25 & 210,25 & 4,945 & 4,20 & 7,77 \\
\hline Kemandirian Belajar (B) & 1 & 200,69 & 200,69 & 4,721 & 4,20 & 7,77 \\
\hline Interaksi $(\mathrm{AXB})$ & 1 & 1980,25 & 1980,25 & 46,579 & 4,20 & 7,77 \\
\hline Dalam & 32 & 1360,44 & 42,51 & & & \\
\hline Total Direduksi & 35 & 3751,64 & & & & \\
\hline
\end{tabular}

Hipotesis pertama berdasarkan perhitungan Anava dua jalur diperoleh, sikap siswa Fhitung untuk metode pembelajaran sebesar 4,945 sedangkan $\mathrm{F}_{\text {tabel }}=4,20$ pada taraf nyatanya $\alpha=0,05$, karena nilai $\mathrm{F}_{\text {hitung }}>\mathrm{F}_{\text {tabel, }}$ maka (Ho) ditolak dan $\mathrm{H}_{1}$ diterima, hal ini menunjukan bahwa terdapat perbedaan sikap antara siswa yang mengikuti metode pembelajaran TPS dan konvensional.

Tabel 2.

Rangkuman Uji Hipotesis Sikap Siswa yang Mengikuti Metode Pembelajaran TPS dan Metode Pembelajaran Konvensional

\begin{tabular}{|c|c|c|}
\hline $\begin{array}{c}\text { Kelompok yang } \\
\text { dibandingkan }\end{array}$ & F $_{\text {hitung }}$ & $\mathbf{F}_{\text {tabel }}$ \\
\cline { 3 - 3 } & & $\boldsymbol{\alpha}=\mathbf{0 , 0 5}$ \\
\hline $\mathrm{A}_{1}$ dan $\mathrm{A}_{2}$ & 4,945 & 4,20 \\
\hline
\end{tabular}

Keterangan :

$\mathrm{A}_{1}$ : Metode Pembelajaran TPS

$\mathrm{A}_{2}$ : Metode Pembelajaran Konvensional

Hipotesis kedua, perhitungan Anava dapat menunjukan Fhitung untuk faktor interaksi yaitu 46,579 lebih besar daripada $F_{\text {tabel }}$ yaitu 4,20 pada taraf nyata $\alpha=0,05$. artinya terdapat pengaruh interaksi antara penggunaan metode pembelajaran dan kemandirian belajar terhadap sikap siswa. Sehingga dapat disimpulkan Ho ditolak dan $\mathrm{H}_{1}$ diterima, artinya tedapat pengaruh interaksi antara penggunaan metode pembelajaran dengan kemandirian belajar terhadap sikap siswa. 
Tabel 3.

Rangkuman Uji Hipotesis Pengaruh Interaksi antara Penggunaan Metode Pembelajaran dan Kemandirian Belajar

\begin{tabular}{|c|c|c|}
\hline $\begin{array}{c}\text { Kelompok yang } \\
\text { dibandingkan }\end{array}$ & F $_{\text {hitung }}$ & $\mathbf{F}_{\text {tabel }}$ \\
\cline { 3 - 3 } & & $\boldsymbol{\alpha}=\mathbf{0 , 0 5}$ \\
\hline $\mathrm{A}_{1} \mathrm{~B}_{1}$ dan $\mathrm{A}_{2} \mathrm{~B}_{2}$ & 46,579 & 4,20 \\
\hline
\end{tabular}

Keterangan :

$\mathrm{A}_{1} \mathrm{~B}_{1}$ : Sikap siswa dengan kemandirian belajar tinggi yang menggunakan metode pembelajaran TPS.

$\mathrm{A}_{2} \mathrm{~B}_{2}$ : Sikap siswa dengan kemandirian belajar rendah yang menggunakan metode pembelajaran konvensional.

Hipotesis ketiga, nilai rerata sikap siswa dengan kemandirian belajar tinggi yang mengikuti metode pembelajaran TPS $\left(\mathrm{A}_{1} \mathrm{~B}_{1}\right)$ adalah 203.89 sedangkan nilai rerata sikap siswa dengan kemandirian belajar yang mengikuti metode pembelajaran konvensional $\mathrm{A}_{2} \mathrm{~B}_{1}$ adalah 184.22 keduanya dibandingkan dengan menggunakan uji tuckey.

Hasil menunjukan bahwa Qhitung yaitu 9,05 > Q tabel yaitu 4,04 pada taraf signifikansinya $\alpha=0,05$ berarti dapat dismpulkan $\mathrm{H}_{0}$ ditolak dan $\mathrm{H}_{1}$ diterima, artinya siswa yang mempunyai kemandirian belajar tinggi terdapat perbedaan sikap belajar dengan siswa yang mengikuti metode pembelajaran konvensional. Berikut adalah tabel rangkuman hasil uji tuckey:

Tabel 4.

Rangkuman Uji Tuckey Sikap Siswa Untuk Kelompok Kemandirian

Belajar Tinggi yang Mengikuti Metode Pembelajaraan TPS dan Metode Pembelajaran Konvensional

\begin{tabular}{|c|c|c|}
\hline $\begin{array}{c}\text { Kelompok yang } \\
\text { dibandingkan }\end{array}$ & Q $_{\text {hitung }}$ & $\mathbf{Q}_{\text {tabel }}$ \\
\cline { 3 - 3 } & & $\boldsymbol{\alpha}=\mathbf{0 , 0 5}$ \\
\hline $\mathrm{A}_{1} \mathrm{~B}_{1}$ dan $\mathrm{A}_{2} \mathrm{~B}_{1}$ & 9,05 & 4,04 \\
\hline
\end{tabular}

Keterangan :

$\mathrm{A}_{1} \mathrm{~B}_{1}$ : Sikap siswa dengan kemandirian belajar tinggi yang mengikuti metode pembelajaran TPS.

$\mathrm{A}_{2} \mathrm{~B}_{1}$ : Sikap siswa dengan kemandirian belajar tinggi yang mengikuti metode pembelajaran konvensional

Hipotesis keempat, nilai rerata sikap siswa dengan kemandirian belajar rendah yang mengikuti metode pembelajaran TPS $\left(\mathrm{A}_{1} \mathrm{~B}_{2}\right)$ adalah 184,33, sedangkan nilai rerata sikap siswa dengan kemandirian belajar rendah yang mengikuti metode pembelajaran konvensional $\left(\mathrm{A}_{2} \mathrm{~B}_{2}\right)$ adalah 194,33. Artinya bahwa Qhitung yaitu 4,60 lebih besar daripada Qtabel yaitu 4,04 
pada taraf signifikasinya $\alpha=0,05$, sehingga dapat disimpulkan $\mathrm{H}_{0}$ ditolak dan $\mathrm{H}_{1}$ diterima, artinya terdapat perbedaan sikap siswa yang memiliki kemandirian belajar rendah yang mengikuti metode TPS dan siswa yang memiliki kemandirian belajar rendah yang mengikuti metode pembelajaran konvensional.

Tabel 5.

Rangkuman Uji Tuckey Sikap Siswa Untuk Kelompok Kemandirian Belajar Rendah Yang Mengikuti Metode Pembelajaran TPS dan Metode Pembelajaran Konvensional

\begin{tabular}{|c|c|c|}
\hline \multirow{2}{*}{$\begin{array}{c}\text { Kelompok yang } \\
\text { dibandingkan }\end{array}$} & Q $_{\text {hitung }}$ & $\mathbf{Q}_{\text {tabel }}$ \\
\cline { 3 - 3 } & & $\boldsymbol{\alpha}=\mathbf{0 , 0 5}$ \\
\hline $\mathrm{A}_{1} \mathrm{~B}_{2}$ dan $\mathrm{A}_{2} \mathrm{~B}_{2}$ & 4,60 & 4,04 \\
\hline
\end{tabular}

Keterangan :

$\mathrm{A}_{1} \mathrm{~B}_{2}$ : sikap siswa dengan kemandirian belajar rendah yang mengikuti metode pembelajaran TPS.

$\mathrm{A}_{2} \mathrm{~B}_{2}$ : Sikap siswa dengan kemandirian belajar rendah yang mengikuti metode pembelajaran konvensional.

\section{PEMBAHASAN}

Berdasarkan pada data hasil penelitian dapat disimpulkan bahwa penggunaan metode pembelajaran TPS memiliki pengaruh yang lebih besar dalam mengoptimalkan sikap siswa di SMA Negeri 3 Karawang dibandingkan dengan metode konvensional.

Hasil pengujian hipotesis pertama menunjukkan bahwa sikap siswa yang mengikuti metode pembelajaran TPS lebih tinggi dari sikap siswa yang mengikuti metode pembelajaran konvensional. Pembelajaran dengan menggunakan metode TPS membuat siswa lebih aktif dan partisipatif karena mereka merasa berkontribusi secara langsung sehingga merasa bertanggungjawab pada pembelajaran sejarah dan nilai-nilai yang diajarkan dari materinya.

Hasil Uji Tuckey pada hipotesis kedua menunjukan adanya pengaruh interaksi antara pengguanaan metode pembalajaran dan kemandirian belajar terhadap sikap siswa, dengan demikian pemilihan metode TPS dianggap tepat dan sesuai untuk dapat memperbaiki sikap siswa.

Hasil uji hipotesis ketiga menunjukan bahwa sikap siswa yang memiliki kemandirian belajar tinggi dan mengikuti metode pemeblajaran TPS lebih tinggi dari sikap siswa yang memiliki kemandirian belajar tinggi dan mengikuti metode pembelajaran konvensional, dengan demikian metode pembelajaran TPS berpengaruh meningkatkan sikap siswa dibandingkan dengan metode konvensional. Siswa yang memiliki 
kemandirian belajar mampu mengikuti metode pembalaran TPS dengan baik, karea metode ini membuat siswa lebih aktif dan berkontribusi akibat tanggungjawab yang sama setiap siswa dalam mencari dan menyelesaikan permasalahan materi pelajaran. Dan dengan TPS siswa mampu mengimplemntasikan sikap disiplin di kelas dari pelajaran sejarah dengan materi perang dunia.

Hasil pengujian hipotesis keempat menunjukan bahwa sikap siswa yang memiliki kemandirian belajar rendah yang mengikuti metode pemeblajaran TPS lebih rendah dari hasil sikap siswa yang memiliki kemandirian belajar rendah yang mengikuti metode pembelajaran konvensional. Hasil analisis Uji Tuckey, siswa yang memiliki kemandirian belajar rendah apabila mengikuti metode pembelajaran TPS maka sikapnya lebih rendah dari siswa yang mengikuti metode pembelajaran konvensional. Hal ini terjadi karena pada pembelajaran dengan metode TPS, siswa yang memiliki kemandirian rendah kurang mempunyai inisiatif dalam mencari informasi dan memecahkan masalah materi pembelajaran baik secara individu atau dengan pasangan kelompoknya, siswa sulit untuk berkomunikasi mengenai materi dengan temanya sehingga sikap yang ditunjukanya kurang baik.

Siswa yang memiliki kemandirian belajar rendah lebih tepat menggunakan metode pembelajaran konvensional karena metode ini tidak mengharuskan keaktifan siswa secara masif seperti pada metode TPS. Pada metode konvensional guru biasanya memberikan ceramah meskipun sesekali terdapat sesi tanya jawab dengan siswa namun peran siswa kurang aktif seperti pada metode TPS sehingga siswa yang memiliki kemandirian belajar rendah sangat tepat dengan metode konvensional.

\section{PENUTUP}

Hasil dari hipotesis dapat disimpulkan bahwa 1) Berdasarkan penelitian, bahawa sikap siswa yang mengikuti metode pembelajaran TPS lebih tinggi dari pada sikap siswa yang mengikuti metode pembelajaran konvensional. 2) Terdapat pengaruh interaksi antara metode pembelajaran dan kemandirian belajar terhadap sikap siswa pada pembelajaran sejarah. 3) Sikap siswa yang mengikuti metode pembelajaran TPS dengan kemandirian belajar tinggi lebih tinggi dari sikap siswa yang mengikuti metode pembelajaran konvensional dengan kemandirian belajar tinggi. 4) Sikap siswa yang mengikuti metode pembelajaran TPS dengan kemandirian belajar rendah lebih rendah dari pada sikap siswa yang mengikuti metode pembelajaran konvensional dengan kemandirian belajar rendah.

Implikasi pada penelitian ini 1) Metode pembelajaran TPS dapat dijadikan sebagai metode pembelajaran yang efektif sebagai pengaruh positif 
terhadap sikap siswa. 2) Penerapan metode pembelajaran TPS, hendaknya mempertimbangkan tingkat kemandirian belajar siswa. 3) Siswa yang memiliki tingkat kemandirian belajar tinggi lebih baik menggunakan metode pembelajaran TPS karena dapat membuat siswa lebih aktif mencari informasi dan berdiskusi mengenai permasalahan materi yang diberikan guru. 4) Penerapan metode pembelajaran konvensional lebih baik digunakan pada siswa yang memiliki tingkat kemandirian belajar rendah.

Saran dari hasil penelitian ini sebagai berikut: 1) Jika guru ingin meningkatkan sikap siswa di SMA maka dianjurkan untuk menggunakan metode pembelajaran TPS. 2) Adanya sosialisasi dari pihak sekolah kepada guru mengenai metode TPS namun tetap memperhatikan tingkat kemandirian belajar siswa 3) Metode pembelajaran TPS dapat diterapkan untuk meningkatkan sikap siswa yang memiliki tingkat kemandirian belajar tinggi. 4) Siswa yang memiliki tingkat kemandirian belajar rendah lebih baik menggunakan metode pembelajaran konvensional.

\section{DAFTAR PUSTAKA}

[1] Hamzah. B. U. (2008). Orientasi Baru Dalam Psikologi Pembelajaran. Jakarta: Bumi Aksara.

[2] Jhonson. B.E. (2014). CTL (Contextual teaching \& Learning) Menjadikan Kegiatan Belajar Mengajar Mengasyikan dan Bermakna. Bandung: Penerbit Kaifa.

[3] Joyce, dkk.(2009). Models of Teaching : Model-model Pengajaran. Yogyakarta: Pustaka Pelajar.

[ 4 ] Kauchak, Eggen. P. (2012). Strategi dan Model Pembelajaran Mengajarkan Konten dan Keterampilan Berpikir, Jakarta: PT Indeks.

[5] Robert M, G. (2002). Kondisi Belajar dan Tes Pembelajaran Terjemahan Munandir. Jakarta: PAU Dirjen Dikti Depdikbud.

[ 6 ] Winkel.(2014). Psikologi Pengajaran, Yogyakarta: Sketsa. 